\title{
Environmental Behaviour of Metolachlor and Diuron in a Tropical Soil in the Central Region of Brazil
}

\author{
Eliana F. G. C. Dores • Cláudio A. Spadotto • \\ Oscarlina L. S. Weber • Leandro Carbo • \\ Antonio B. Vecchiato • Alicio A. Pinto
}

Received: 17 December 2007 / Accepted: 15 July 2008 / Published online: 12 September 2008

(C) Springer Science + Business Media B.V. 2008

\begin{abstract}
The environmental behaviour of metolachlor and diuron was studied in the Central-western region of Brazil, by means of a field study where six experimental plots were installed. The soil was classified as a Latosol, and the soil horizons were
\end{abstract}

E. F. G. C. Dores $(\bowtie) \cdot$ A. A. Pinto

Department of Chemistry, ICET,

Universidade Federal de Mato Grosso,

Av. Fernando Correa, s/n.,

CEP-78060-900 Cuiabá, Mato Grosso, Brazil

e-mail: eliana@ufmt.br

C. A. Spadotto

Embrapa Environment, CP 69,

13820-000 Jaguariúna, São Paulo, Brazil

\section{O. L. S. Weber}

Department of Soil and Rural Engineering, FAMEV, Universidade Federal de Mato Grosso,

Av. Fernando Correa, s/n.,

CEP-78060-900 Cuiabá, Mato Grosso, Brazil

L. Carbo

Pos-graduation in Chemistry, Institute of Chemistry,

Universidade Estadual Paulista,

Av. Prof. Franscisco Degni s/n.,

14801-970 Araraquara, São Paulo, Brazil

\section{A. B. Vecchiato}

Department of Geology, ICET,

Universidade Federal de Mato Grosso,

Av. Fernando Correa s/n.,

CEP-78060-900 Cuiabá, Mato Grosso, Brazil characterized. Sorption of metolachlor and diuron was evaluated in laboratory batch experiments. Metolachlor and diuron were applied to the experimental plots on uncultivated soil in October 2003. From this date to March 2004, the following processes were studied: leaching, runoff and dissipation in top soil. $K_{\mathrm{oc}}$ of metolachlor varied from 179 to $264 \mathrm{~mL} \mathrm{~g}^{-1}$ in the soil horizons. $K_{\mathrm{oc}}$ of diuron in the Ap horizon was $917 \mathrm{~mL} \mathrm{~g}^{-1}$, decreasing significantly in the deeper horizons. Field dissipation half-lives of metolachlor and diuron were 18 and 15 days, respectively. In percolated water, metolachlor was detected in concentrations ranging from 0.02 to $2.84 \mu \mathrm{g} \mathrm{L} \mathrm{L}^{-1}$. In runoff water and sediment, metolachlor was detected in decreasing concentrations throughout the period of study. Losses of $0.02 \%$ and $0.54 \%$ of the applied amount by leaching and runoff, respectively, were observed confirming the high mobility of this herbicide in the environment. In percolated water, diuron was detected with low frequency but in relatively high concentrations (up to $6.29 \mu \mathrm{g} \mathrm{L}^{-1}$ ). In runoff water and soil, diuron was detected in decreasing concentrations until 70 days after application, totalizing $13.9 \%$ during the whole sampling period. These results show the importance of practices to reduce runoff avoiding surface water contamination by these pesticides, particularly diuron.

Keywords Sorption - Leaching - Runoff .

Dissipation $\cdot$ Pesticides 


\section{Introduction}

Contamination of water resources by agricultural chemicals is a worldwide environmental problem. The dependence of agriculture on the use of potentially toxic compounds and the vulnerability of the natural resources to pollution by agrochemicals pose a dilemma for agricultural and environmental regulators as discussed by Bernard et al. (2005). When a pesticide is applied to the soil surface, the initial concentration at the topsoil immediately begins to diminish due to microbial and chemical (including photochemical) degradation and to volatilization. Rainfall causes further dissipation from the soil surface through both runoff and leaching processes (Southwick et al. 2003).

Field investigations of pesticide fate in tropical regions indicate that dissipation often occurs more rapidly than for those used under comparable temperate conditions (Laabs et al. 2002). The most prominent mechanisms for this acceleration in pesticide dissipation appear to be related to the effect of tropical climates, and would include increased volatility and enhanced chemical and microbial degradation rates on an annualized basis. As stated by Racke (2003), although the published literature contains a number of reports and summaries of the behavior of pesticides in tropical ecosystems, further experimental and modeling research targeted at developing a more complete understanding and better predictive capability of the behavior of pesticides under tropical environmental conditions should be encouraged.

Soils with high clay and silt contents and that contain an aggregated structure with large porosity and hydraulic conductivity values combined with high rainfall intensities, may suffer from high leaching fluxes below the root zone compared to temperate regions (Bernard et al. 2005). In addition, increased rates of volatilization, photolysis, and chemical and biological degradation of pesticides can be expected due to higher air and soil temperatures with smaller seasonal variations than in temperate regions (Laabs et al. 2002).

Metolachlor and diuron are herbicides frequently used in soya and cotton crops in Central-western Brazil. These herbicides are known as potential groundwater contaminants (Crisanto et al. 1995; Laabs et al. 2000; Singh et al. 2002; Caracciolo et al. 2005). Considering the model of agriculture developed in the studied region, in vast farm areas, highly mechanized cash-crop production systems and highly dependent on chemicals (pesticides and fertilizers), it is important to study the dynamics of pesticides in this environment. Thus, this study aimed to evaluate the dynamics of metolachlor and diuron in a tropical environment, emphasizing sorption, leaching, runoff and field dissipation. The obtained results may contribute to the risk assessment of surface and groundwater contamination by metolachlor and diuron.

\section{Materials and Methods}

\subsection{Field Sampling System}

In a cotton farm, a $180 \times 80 \mathrm{~m}$ area was isolated and six $5 \times 10 \mathrm{~m}$ experimental plots were set up. In each plot, one lysimeter, one run-off collector system and one monitoring well were installed as shown in Fig. 1. The six plots were located in two lines parallel to the river. Two trenches were dug along the direction of these two lines and samples from the different soil horizons were collected. Trenches dimensions were: depth $2 \mathrm{~m}$, length $2 \mathrm{~m}$ and width $1 \mathrm{~m}$. Physical-

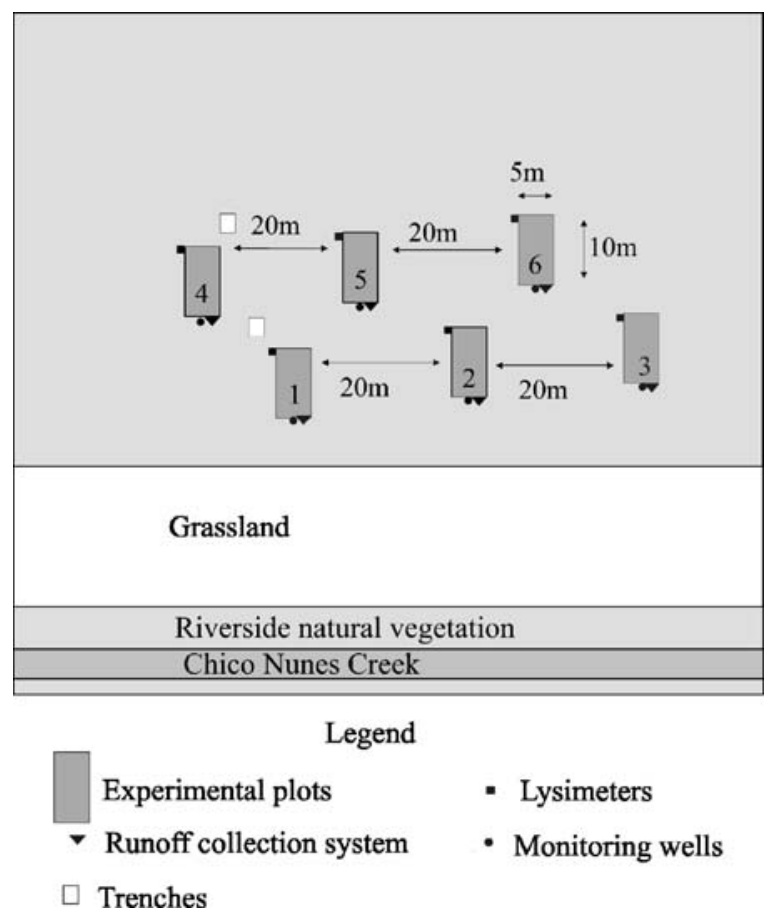

Fig. 1 Scheme of the experimental area 
chemical properties of the soils in these horizons were determined following the methods described in EMBRAPA (1999a). Metolachlor and diuron were applied by coastal pulverization, on 15 October 2003 . Metolachlor and diuron were applied at a dose of 1.25 $\mathrm{L} \mathrm{ha}^{-1}$ (commercial product formulated as a concentrated suspension at $960 \mathrm{~g} \mathrm{~L}^{-1}$ ) and $4.0 \mathrm{~L} \mathrm{ha}^{-1}$ (commercial product formulated as a concentrated suspension at $500 \mathrm{~g} \mathrm{~L}^{-1}$ ), respectively, as recommended for use in cotton crops.

Lysimeter installation and gravity sampling were performed as described by Laabs et al. (2002). Six lysimeters $(50 \mathrm{~cm}$ deep) were installed by means of six small trenches opened bordering the upper part of the plot. Monitoring wells were installed at the lower end of the experimental plots for monthly water table sample collection. Depth of monitoring wells varied from 3.8 to $4.2 \mathrm{~m}$.

To evaluate the amount of herbicides lost from the field by runoff, a collection system composed of a triangular recipient $(2.5 \times 2.5 \times 2.5 \mathrm{~m})$ was installed at the lower end of the plot. Water was drained from the collector via a tap and the remained deposited sediment was withdrawn using a scoop. Water volume and run-off sediment mass were measured at each sampling date.

Field sampling started at the application date and lasted till March 2004. Topsoil $(0-10 \mathrm{~cm})$ samples for field dissipation study were collected in preestablished dates: $0,1,2,4,8,16,32,64$ and 128 days after application. Composite sampling soil positions were chosen randomly in a grid system, avoiding subsequent collection from the same points. Percolated water from lysimeters, runoff water and sediment were collected per event. Water samples from monitoring wells were collected monthly. Water table level ranged from $3.1 \mathrm{~m}$ (October 2003) to $0.5 \mathrm{~m}$ (March 2004) below soil surface.

Residues of metolachlor and diuron were determined in these samples as described below.

\subsection{Chemicals}

Analytical grade metolachlor and diuron were purchased from Dr. Ehrenstorfer (Augsburg, Germany) and used as analytical standards. Solvents (acetone, acetonitrile, ethyl acetate, hexane, dichloromethane and methanol) were HPLC grade provided by Mallinckrodt Baker (Paris, KY, USA). Sorbents used were SDVB (polystyrenedivinylbenzene) from Supelco (Supelclean ENVI-Chrom P) and octadecylsilica (C18) from J.T. Baker.

\subsection{Analytical Instrumentation}

For diuron analysis and sorption assays a Varian HPLC system equipped with a 410 autosampler, a 240 quaternary pump and 330 UV diode-array detector controlled by a personal computer running the software Varian ProStar, version 5.5 (Varian, USA) was used. Both, the analytical column $(250 \times$ $4.6 \mathrm{~mm}$ I.D. $)$ and the guard column $(20 \times 4.6 \mathrm{~mm}$ I.D. $)$ were Omnisphere $5 \mu \mathrm{m} \mathrm{C}_{18}$.

For metolachlor analysis a gas chromatograph HP 6890 with mass selective detector HP 5973 (HewlettPackard GmbH, Germany), split/splitless injector, with a HP-5MS (5\% phenylmethylsiloxane) column ( $30 \mathrm{~m} \times$ $250 \mu \mathrm{m} \mathrm{id} \times 0.25 \mu \mathrm{m}$ phase thickness) was used.

\subsection{Soil Sorption Determination}

Samples from the three soil horizons (Ap, BA and Bw1) were used to calculate sorption coefficients of metolachlor and diuron, which were determined in batch experiments. Soil samples were air-dried for $48 \mathrm{~h}$, sieved through a \#10 metal sieve (Tyler equivalent nine mesh, opening $2 \mathrm{~mm}$ ). $5.0 \mathrm{~g}$ of soil was weighed in $125 \mathrm{~mL}$-erlenmeyer and $25 \mathrm{~mL}$ of calcium chloride $\left(\mathrm{CaCl}_{2}\right)$ solution $0.01 \mathrm{~mol} \mathrm{~L}^{-1}$ were added, as a background electrolyte to mimic realistic soil ionic strength and to help flocculation of clay particles. This mixture was fortified with each pesticide by adding proper aliquots of stock solutions (c.a. $100 \mu \mathrm{g} \mathrm{mL}^{-1}$ ) prepared in methanol in order to reach increasing concentrations: $1.0 ; 2.0 ; 4.0 ; 8.0$ and $16.0 \mu \mathrm{g} \mathrm{mL}^{-1}$. The soils were agitated in a mechanical shaker at $140 \mathrm{rpm}$ for $24 \mathrm{~h}$, to reach equilibrium. Several authors (Gaillardon and Dur 1995; Inoue et al. 2004; Liyanage et al. 2006) have demonstrated that generally pesticide equilibrium in the batch solution is reached in less than $24 \mathrm{~h}$. All experiments were performed in duplicate and one blank sample was included in every sample batch to check for interfering peaks.

The solution was filtered in quantitative filter paper followed by glass fiber membrane $(0.45 \mu \mathrm{m})$. An $1.0 \mathrm{~mL}$ aliquot from the filtrate was transferred to an autosampler vial and analyzed in a liquid chromatograph with UV-diode array detector at $230 \mathrm{~nm}$. An 
aliquot $(20 \mu \mathrm{L})$ was injected into the HPLC column and eluted at room temperature at a constant flow-rate of $1 \mathrm{~mL} \mathrm{~min}^{-1}$ using acetonitrile:water $(30: 70 \mathrm{v} / \mathrm{v})$.

\subsection{Sample Extraction and Analysis}

In water samples, diuron was extracted using SDVB cartridges $(0.2 \mathrm{~g})$ previously conditioned with $5 \mathrm{~mL}$ of methanol and $5 \mathrm{~mL}$ of water. The water sample $(500 \mathrm{~mL})$ was pre-concentrated in the cartridge under vacuum which was kept on for $30 \mathrm{~min}$, to dry the adsorbent. Diuron residues were eluted with three portions of $5 \mathrm{~mL}$ methanol:acetonitrile (7:3). The eluate was concentrated in a vacuum rotary evaporator at $45^{\circ} \mathrm{C}$. The residue was redissolved with c.a. $1 \mathrm{~mL}$ of acetonitrile and was transferred to an autosampler vial to which $50 \mu \mathrm{L}$ of terbuthylazine standard solution $\left(100 \mu \mathrm{g} \mathrm{mL}^{-1}\right)$ was added, as internal standard.

For soil analysis, a $15-\mathrm{g}$ soil aliquot was weighed in a centrifuge tube to which $40 \mathrm{~mL}$ of an extracting solvent mixture (acetone:acetonitrile:pH $2 \mathrm{KCl} / \mathrm{HCl}$ buffer solution, 2:2:1) was added. The tube was agitated for $3.5 \mathrm{~h}$ in an orbital shaker and then centrifuged at $1,600 \mathrm{rpm}$. The supernatant was transferred to a beaker, $180 \mathrm{~mL}$ ultrapurified Milli-Q water were added and $\mathrm{pH}$ was raised back to 7.0-7.5. This extract was cleaned-up in an SDVB cartridge $(0.2 \mathrm{~g})$ pre-conditioned with $5 \mathrm{~mL}$ methanol and $5 \mathrm{~mL}$ ultrapurified Milli-Q water. After pre-concentration, the cartridge was centrifuged to eliminate residual water and diuron residues were eluted with $2 \times 10 \mathrm{~mL}$ and $1 \times 5 \mathrm{~mL}$ of methanol: acetontrile (7:3). The final extract was concentrated in rotary evaporator to near dryness, redissolved in acetonitrile and transferred to an autosampler vial to which $50 \mu \mathrm{L}$ of terbuthylazine standard solution $\left(100 \mu \mathrm{g} \mathrm{mL}^{-1}\right)$ was added, as internal standard.

An aliquot $(20 \mu \mathrm{L})$ was injected into the HPLC column and eluted at room temperature at a constant flow-rate of $1 \mathrm{~mL} \mathrm{m^{-1 }}$ under the following conditions. The analytes were eluted with acetonitrile:water with initial composition of $20 \%$ acetonitrile, increasing to $40 \%$ at $6 \mathrm{~min}, 80 \%$ at $20 \mathrm{~min}$, and $100 \%$ at $30 \mathrm{~min}$, where it was kept constant for $3 \mathrm{~min}$ and then linearly decreased to the initial conditions within $10 \mathrm{~min}$. The detection and quantification were performed at $230 \mathrm{~nm}$. Diuron was identified by its retention time and identification was confirmed by comparison of its UV spectra to that of standard solutions. Detection and quantification limits for diuron were 3 and $10 \mu \mathrm{g} \mathrm{kg}^{-1}$ in soil samples and 0.07 and $0.42 \mu \mathrm{g} \mathrm{L}^{-1}$ in water, respectively.

In water, metolachlor was determined by SPE extraction using C-18 cartridges as described by Laabs et al. (2000). For metolachlor analysis in soil, the extraction method consisted on a solid-liquid extraction step using an extraction system of acetone, ethyl acetate and water $(2: 2: 1, v / v / v)$ with mechanical agitation followed by a liquid-liquid purification step with dichloromethane and final concentration in rotary evaporator. To a $20 \mathrm{~g}$ soil sample $5 \mu \mathrm{g}$ of internal standards in acetone $(\alpha-\mathrm{HCH})$ were added prior to extraction to facilitate pesticide quantification and control method recovery. Final extracts were redissolved in toluene. Full details of the extraction method were described previously (Laabs et al. 1999).

Metolachlor was quantified with GC-MS operated in the selected ion-monitoring mode at the following conditions: injector block temperature $=250^{\circ} \mathrm{C}$; carrier gas $=$ helium; oven temperature program $=$ initial temperature of $92^{\circ} \mathrm{C}$ held for $2.5 \mathrm{~min}$, heating up to $175^{\circ} \mathrm{C}$ at $15^{\circ} \mathrm{C} \mathrm{min}^{-1} ; 175^{\circ} \mathrm{C}$ held for $13 \mathrm{~min}$, heating up to $280^{\circ} \mathrm{C}$ at $20^{\circ} \mathrm{C} \mathrm{min}^{-1}, 280^{\circ} \mathrm{C}$ held for $9 \mathrm{~min}$; and transfer-line temperature $=290^{\circ} \mathrm{C}$. Calibration was performed using internal standard, alfa-HCH. Detection and quantification limits were 0.01 and $0.03 \mu \mathrm{g}$ $\mathrm{L}^{-1}$ in water and 0.5 and $3.5 \mu \mathrm{g} \mathrm{kg}^{-1}$ in soil.

\subsection{Dissipation of Pesticides}

Pesticide dissipation was modeled using monoexponential decay models derived from Eq. 1:

$C(t)=C_{1} \exp (-k . t)+C_{2}$

with $C_{1}+C_{2}=C_{0}$.

In this formula, $t$ represents time, $C(t)$ denotes the concentration of pesticide still present in the soil at time $t, k$ is the dissipation rate constant, $C_{0}$ is the initial concentration of pesticides in the soil, and $C_{1}$ and $C_{2}$ are fractions of the initial pesticide concentration.

\section{Results and Discussion}

\subsection{Experimental Area}

Soil in the experimental area was classified as a Yellow Latosol according to Brazilian Soil Classification System (EMBRAPA 1999b) which corresponds 
to Oxysol according to the classification of Soil Taxonomy (USDA 2006). The physical-chemical properties of the soil horizons in the study area are presented in Table 1. This soil is slightly acidic, sandy-clayey with increasing clay content with depth. This variation leads to a greater water retention capacity in deeper soil horizons.

Slope of experimental plots varied from $3.6 \%$ to $4.7 \%$, which characterizes an undulating, very gently sloping soil (USDA 2006). The average basic infiltration rate is $58.6 \mathrm{~mm} \mathrm{~h}^{-1}$. Despite the high infiltration rate and relatively low declivity, run-off is a common occurrence due to intense rainfall events.

During the sampling period there was a total precipitation of $1,746.5 \mathrm{~mm}$, with a monthly precipitation of $244 ; 212.5 ; 472.5 ; 484 ; 173.5$ and $160 \mathrm{~mm}$ from November 2003 to April 2004. The first rain event occurred 20 days after application of herbicides.

Average $(n=6)$ total water and soil loss during the experimental period per plot area were $3.8 \mathrm{~m}^{3}$ and $27.6 \mathrm{~kg}$ respectively, which extrapolating correspond to $1,510 \mathrm{~m}^{3} \mathrm{ha}^{-1}$ and 11 ton $\mathrm{ha}^{-1}$, respectively.

\subsection{Soil Sorption}

The sorption coefficient of metolachlor $\left(K_{\mathrm{D}}\right)$ was $3.1 \mathrm{~mL} \mathrm{~g}^{-1}$ in Ap, $3.9 \mathrm{~mL} \mathrm{~g}^{-1}$ in BA and $1.8 \mathrm{~mL} \mathrm{~g}^{-1}$ in Bw1 horizons which normalized to organic carbon $\left(K_{\mathrm{oc}}\right)$ ranged from 179 to $261 \mathrm{~mL} \mathrm{~g}^{-1}$, values similar to those reported in the literature (Hornsby et al. 1996). No significant variation was observed in the three horizons. These values are relatively low, indicating that metolachlor is moderately mobile in soil and presents a potential for groundwater contamination as reported by Crisanto et al. (1995); Laabs et al. (2000) and Singh et al. (2002).

For diuron $K_{\mathrm{D}}$ varied from $3.1 \mathrm{~mL} \mathrm{~g}^{-1}$ in Bw1 and $2.7 \mathrm{~mL} \mathrm{~g}^{-1}$ in $\mathrm{A} / \mathrm{B}$ to $14.7 \mathrm{~mL} \mathrm{~g}^{-1}$ in Ap horizons (corresponding to $K_{\mathrm{oc}}$ from 145 to $917 \mathrm{~mL} \mathrm{~g}^{-1}$ ). These values fall within the range reported by
Liyanage et al. (2006), who studied sorption of diuron in 43 tropical soils in Sri Lanka. It appears that the main contributor to diuron adsorption is the organic matter content although it does not explain alone the differences in sorption in these three horizons, as also observed by Liyanage et al. (2006). The $K_{\text {oc }}$ value reported in our study for the topsoil horizon is higher than those reported by Souza et al. (2000) in a Latosol in Southeastern Brazil. The much lower adsorption coefficients of diuron in the deeper soil horizon indicate that molecules not retained in the surface are prone to leaching to groundwater due to much lower retention.

Louchart et al. (2005) studying the sorption behaviour of diuron under a Mediterranean climate showed that soil drought plays a major role in modifying the sorption behaviour of herbicides in soil and therefore their availability to transfer by overland flow or infiltration. The drying-wetting cycles that are likely to occur in natural field conditions, particularly in the study region where temperatures get high during the day (up to $35-40^{\circ} \mathrm{C}$ ) drying the soil very quickly, may affect the fate of herbicides in tropical environments. As recommended by those authors these effects should be subject to further studies.

\subsection{Field Dissipation}

Field dissipation data for both herbicides are shown in Table 2 and Fig. 2.

The half-life of metolachlor of 18 days is in agreement to the values reported by Laabs et al. (2000) in a tropical soil similar to the one in this study, but is lower than the values reported in temperate regions (Hornsby et al. 1996; Leu et al. 2004). Several factors may contribute to the reduction of field half life: high air temperatures (monthly average temperatures from $22^{\circ} \mathrm{C}$ to $27^{\circ} \mathrm{C}$ and maximum of up to $\left.38^{\circ} \mathrm{C}\right)$, intense rainfall $(1,746.5 \mathrm{~mm}$
Table 1 Physical-chemical properties of the soil horizons of a Yellow Latosol in Mato Grosso, State, Brazil

Corg Organic carbon

\begin{tabular}{|c|c|c|c|c|c|c|c|}
\hline \multirow[t]{2}{*}{ Soil horizons } & \multirow{2}{*}{$\frac{\text { Depth }}{\mathrm{cm}}$} & \multirow[t]{2}{*}{ Clay } & \multirow{2}{*}{$\frac{\text { Silt }}{\mathrm{g} \mathrm{kg}^{-1}}$} & \multirow[t]{2}{*}{ Sand } & \multirow{2}{*}{$\frac{\mathrm{pH}}{\mathrm{H}_{2} \mathrm{O}}$} & \multicolumn{2}{|l|}{ Corg } \\
\hline & & & & & & $\%$ & $\mathrm{~g} \mathrm{~kg}^{-1}$ \\
\hline Ap & $0-30$ & 316 & 60 & 624 & 5.1 & 1.55 & 15.54 \\
\hline BA & $30-42$ & 450 & 26 & 524 & 5.0 & 0.79 & 7.87 \\
\hline Bw1 & $42-83$ & 484 & 26 & 490 & 5.1 & 0.47 & 4.72 \\
\hline
\end{tabular}


Table 2 Pesticide dissipation $(0-10 \mathrm{~cm})$; standard errors of half-life are shown in parentheses $(n=3)$

\begin{tabular}{lllllll}
\hline Pesticide & $C_{0}\left(\mu \mathrm{g} \mathrm{kg}^{-1}\right)$ & $C_{1}\left(\%\right.$ of $\left.C_{0}\right)$ & $C_{2}\left(\%\right.$ of $\left.C_{0}\right)$ & $k$ (diss. rate $)$ & $r^{2}$ & $t_{0.5}($ days $)$ \\
\hline metolachlor & 933 & 100 & 0 & 0.0382 & 0.920 & $18(5)$ \\
diuron & 834 & 87.9 & 12.1 & 0.0479 & 0.927 & $15(6)$ \\
\hline
\end{tabular}

$C_{0}$ Soil concentration at 0 day after application, $C_{1,2}$ soil fractions of different dissipation dynamics, $k$ dissipation rate

concentrated in 6 months) and soil microbial activities. Since metolachlor is considered moderately mobile (low $K_{\mathrm{oc}}$ ), the high rainfall precipitation during the experiment in a topsoil with a sandy texture, led to an intensified leaching. Moreover, the high air temperature can promote volatilization of herbicides as reported by Laabs et al. (2002) who detected metolachlor in rainwater collected distant from areas where this herbicide was applied.

The half-life of diuron (15 days) are in the same range determined by Bernard et al. (2005) who studied its half-life under laboratory conditions at a temperature of $37^{\circ} \mathrm{C}$ in two tropical soils, finding 16 and 31 days.

Rouchaud et al. (2000) studied diuron dissipation in soil from pear orchards in Belgium, in an area where this herbicide was applied for the first time and in another area where it was applied consecutively during 12 years. They reported a half-life of 81 days in the first case with a reduction to 37 days in the second case, and attributed this difference to microorganisms adaptation which accelerated diuron degradation in the previously exposed soil. In our study, diuron has been applied in the studied field in the previous years. The determined half-life was much shorter than that reported by those authors, probably due to climate differences, since the accumulated rain in our study was about three times the corresponding value in the Belgium study, and probably air and soil temperatures were much higher.

From the determined $K_{\mathrm{oc}}$ values for diuron, it can be consider low to moderately mobile, being strongly retained in the topsoil but slightly retained in the deeper horizons, so the high rainfall precipitation that occurred during the experiment in a topsoil may have caused intensified leaching. The high air temperature could promote volatilization of herbicides as reported by Laabs et al. (2002). However, diuron is considered as a non-volatile chemical, as indicated by its low vapor pressure of $6.90 \times 10^{-8} \mathrm{~mm} \mathrm{Hg}\left(25^{\circ} \mathrm{C}\right)$, and low Henry's law constant of $5.10 \times 10^{-10} \mathrm{~atm} \mathrm{~m}^{3} \mathrm{~mol}^{-1}$.
Losses of diuron via volatilization can be considered insignificant except when diuron is left exposed on the soil surface for several days or weeks under hot, dry conditions (Moncada 2004). In our field study, after the installation of the experimental plots, the first rain event occurred 20 days after application of the herbicides, so volatilization is likely to have occurred.

\subsection{Leaching}

The concentrations of metolachlor in water collected in the lysimeters varied from $0.02 \mu \mathrm{g} \mathrm{L} \mathrm{L}^{-1}$ to $2.84 \mu \mathrm{g}$ $\mathrm{L}^{-1}$. The average mass of leached metolachlor in the lysimeters was $3.037 \mu \mathrm{g}$, representing $0.02 \%$ of the amount applied. In the water table, metolachlor was detected in all samples in concentrations varying from 0.01 to $0.85 \mu \mathrm{g} \mathrm{L}^{-1}$. Water table depth varied from 0.50 a $3.0 \mathrm{~m}$ during the study period. These results confirm that metolachlor can reach the deeper layers of soil in accordance with the observations of Caracciolo et al. (2005). Reichenberger et al. (2002) verified that in an Oxisol from a region near to our study, transport along preferential flow pathways contributed a major part to total pesticide displacement. Thus, metolachlor leaching may have occurred

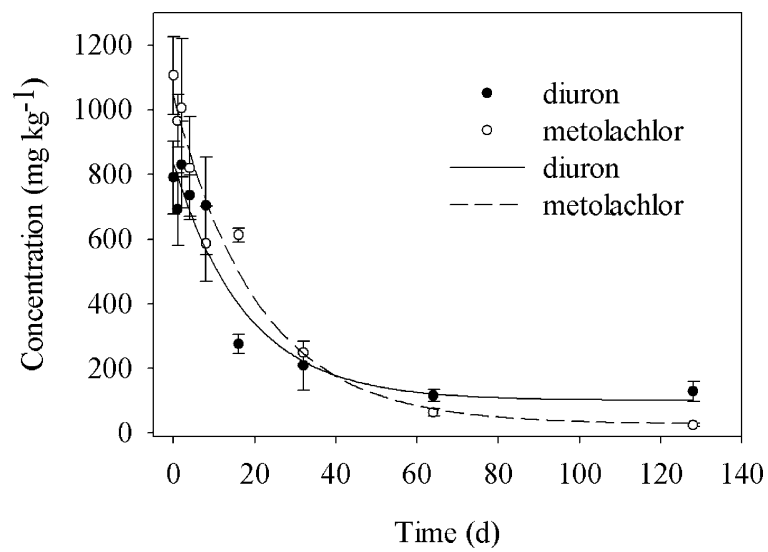

Fig. 2 Field dissipation of metolachlor and diuron 
Fig. 3 Metolachlor concentrations in runoff sediment (a) and water (b) per sampling date
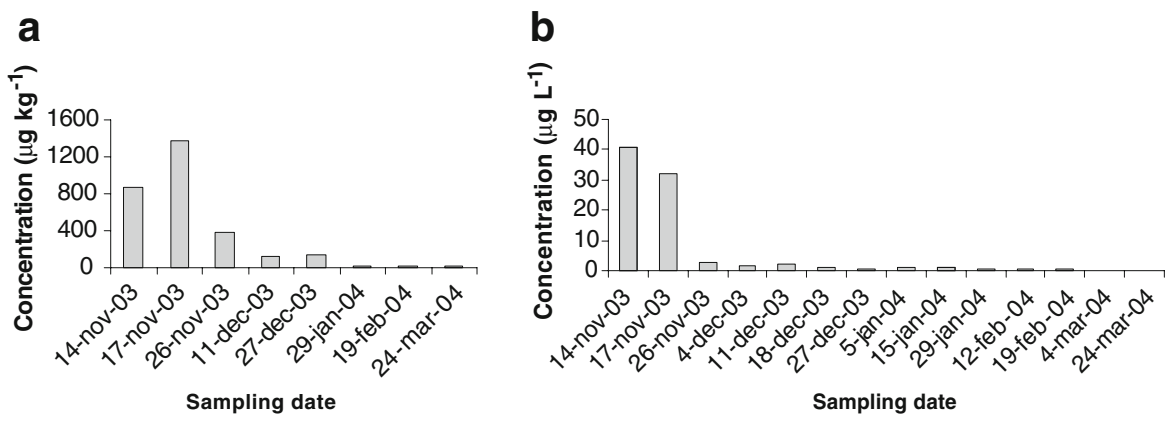

via both matrix flow and preferential flow phenomena through soil macropores.

Diuron concentrations in water collected in the lysimeters varied from 0.02 to $6.29 \mu \mathrm{g} \mathrm{L}^{-1}$ in detected samples. The average mass of leached diuron in the lysimeters was $9.013 \mu \mathrm{g}$, representing $0.08 \%$ of the amount applied. In the water table, diuron was detected only once at $2.32 \mu \mathrm{g} \mathrm{L}^{-1}$.

It is noteworthy that metolachlor is much more volatile (with much higher vapour pressure value) than diuron and, thus, larger losses by volatilization for metolachlor are expected, contributing to its smaller percentage of leaching.

\subsection{Run-off}

In runoff water, metolachlor was transported in high quantities (average total of $18,400 \mu \mathrm{g}$ during the experiment) and in much higher concentrations in the beginning of the sampling period. The mass of metolachlor transported off-site dissolved in water was in average $0.3 \%$ of the applied quantity. On the other side, the total mass of metolachlor associated with the runoff sediment was $14,800 \mu \mathrm{g}$ representing $0.24 \%$ of the applied quantity.
Metolachlor concentration in runoff water and sediment decreased rapidly after the first sampling (Fig. 3). The same was observed by Leu et al. (2004) and Vianello et al. (2005) who reported that the major losses of this herbicide from the agricultural fields occurred during the first two rain events after application which led to significant surface runoff.

In the first runoff event, the ratio of metolachlor concentrations in water/sediment was 0.05 , decreasing to 0.008 after 12 days, indicating that the sorption of this herbicide to soil increased in time.

These data show that from the applied amount of metolachlor, $0.54 \%$ was lost by runoff, during the whole sampling period. So, regarding off-site transport, run-off is more important than leaching $(0.02 \%)$ for this molecule. Southwick et al. (2003), in a study in Southern Louisiana, reported that losses of metolachlor in runoff were $3.7 \%$ to $8.0 \%$, much higher than the values found here.

In runoff water, diuron was transported in high quantities (average total of 193,800 $\mu \mathrm{g}$ during the experiment) with much higher concentrations measured at the beginning of the sampling period (Fig. 4). The mass of diuron transported off-site dissolved in water averaged $3.9 \%$ of the applied quantity. On the
Fig. 4 Diuron concentration in runoff sediment (a) and water (b) per sampling date
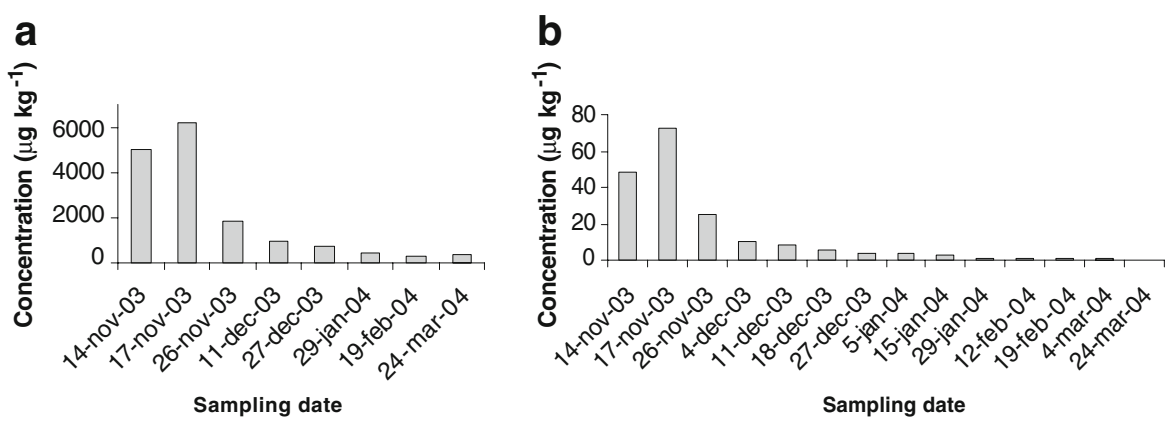
other side, the total mass of diuron associated with the runoff sediment was $488,900 \mu \mathrm{g}$ representing $10 \%$ of the applied quantity. Its relatively high $K_{\mathrm{oc}}$ in topsoil is responsible for the much higher amount transported associated to sediment than dissolved in water.

Thus, from the amount of diuron initially applied in the field, $13.9 \%$ was lost by runoff, during the whole sampling period, a much higher loss when compared to leaching $(0.08 \%)$. As well as with metolachlor, run-off is a major way of diuron off-site transport. Hydrolysis half-life of diuron of 1,490 days at $\mathrm{pH} 5$ and soil photolysis of 173 days (Moncada 2004) indicates that dissipation of diuron in topsoil was due mainly to transport by runoff associated with sediment transport as well as dissolved in water and in smaller extent due to leaching.

Consequently metolachlor and diuron showed to be moderately mobile, and are therefore prone to offsite movement in surface runoff, and migration to ground water. Diuron losses were significantly higher than metolachlor losses.

After the installation of the experimental plots, the first rain event occurred only 20 days after application of the herbicides which intensified degradation and volatilization. Since the field half-life of metolachlor and diuron were 18 and 15 days, when runoff started to occur only approximately half of the applied amount of each herbicide was available to be transported by the rain water. Despite this fact, run-off showed to be an important via of off-site transport.

These findings alert to the high potential for surface water contamination with diuron and metolachlor by runoff in areas with intense rain precipitation. The maintenance of a strip of natural vegetation alongside water resources is needed to prevent contamination (Syversen and Bechmann 2004).

\section{Conclusion}

A loss of $0.02 \%$ and $0.08 \%$ of the applied amount of metolachlor and diuron, respectively, by leaching (reaching $50 \mathrm{~cm}$ below soil surface) was observed indicating a potential groundwater contamination, which was confirmed by the detection of these herbicides in water table, although it occurred just once for the second molecule during the sampling period.

During the whole sampling period, the loss by runoff of metolachlor and diuron totalized $0.54 \%$ and
$13.9 \%$, respectively, showing the importance of practices to reduce runoff and avoid surface water contamination by this pesticide. Moreover, efficiency of weed control may be reduced with such a high loss, especially for diuron.

Acknowledgements We thank FACUAL (Fundo de Apoio à Cultura do Algodão) for financial support.

\section{References}

Bernard, H., Chabalier, P. F., Chopart, J. L., Legube, B., \& Vauclin, M. (2005). Assessment of herbicide leaching risk in two tropical soils of Reunion Island (France). Journal of Environmental Quality, 34, 534-543.

Caracciolo, A. B., Giuliano, G., Grenni, P., Guzzella, L., Pozzoni, F., Bottoni, P., et al. (2005). Degradation and leaching of the herbicides metolachlor and diuron: a case study in an area of Northern Italy. Environmental Pollution, 134(3), 525-534. doi:10.1016/j.envpol.2004. 08.014.

Crisanto, T., Sánchez-Camazano, M., Arienzo, M., \& SánchezMartín, M. J. (1995). Adsorption and mobility of metolachlor in surface horizons of soils with low organic matter content. The Science of the Total Environment, 166(1-3), 69-76. doi:10.1016/0048-9697(95)04475-G.

EMBRAPA - Empresa Brasileira de Pesquisa Agropecuária. Centro Nacional de Pesquisa de Solos (1999a). Manual de métodos de análises de solos. Rio de Janeiro: Embrapa Solos.

EMBRAPA - Empresa Brasileira de Pesquisa Agropecuária. Centro Nacional de Pesquisa de Solos (1999b). Sistema Brasileiro de Classificação de Solos. Rio de Janeiro: Embrapa Solos.

Gaillardon, P., \& Dur, J. C. (1995). Influence of soil moisture on short-term adsorption of diuron and isoproturon by soil. Pesticide Science, 45, 297-303. doi:10.1002/ps. 2780450402.

Hornsby, A., Wauchope, R., \& Herner, A. (1996). Pesticide properties in the environment. New York: Springer.

Inoue, M. H., Oliveira Jr, R. S., Regitano, J. B., Tormena, C. A., Constantin, J., \& Tornisielo, V. L. (2004). Sorption kinetics of atrazine and diuron in soils from southern Brazil. Journal of Environmental Science and Health. Part. B, Pesticides, Food Contaminants, and Agricultural Wastes, 39(4), 589601. doi:10.1081/PFC-200026818.

Laabs, V., Amelung, W., Pinto, A. A., Altstaedt, A., \& Zech, W. (2000). Leaching and degradation of corn and soybean pesticides in an Oxisol of the Brazilian Cerrados. Chemosphere, 41, 1441-1449. doi:10.1016/S0045-6535(99) 00546-9.

Laabs, V., Amelung, W., Pinto, A., \& Zech, W. (2002). Fate of pesticides in tropical soils of Brazil under field conditions. Journal of Environmental Quality, 31, 256-268.

Laabs, V., Amelung, W., \& Zech, W. (1999). Muti-residue analysis of corn and soybean pesticides in Brazilian oxisoils using gas chromatography and mass selective detection. Journal of Environmental Quality, 28, 1778-1786. 
Leu, C., Singer, H., Stamm, C., Müller, S. R., \& Shcwarzenbach, R. P. (2004). Simultaneous assessment of sources, processes, and factors influencing herbicide losses to surface waters in a small agricultural catchment. Environmental Science \& Technology, 38(14), 3827-3834. doi:10.1021/es0499602.

Liyanage, J. A., Watawala, R. C., Aravinna, A. G. P., Smith, L., \& Kookana, R. S. (2006). Sorption of carbofuran and diuron pesticides in 43 tropical soils of Sri Lanka. Journal of Agricultural and Food Chemistry, 54, 1784-1791. doi:10.1021/jf052021o.

Louchart, X., Lennartz, B., \& Voltz, M. (2005). Sorption behaviour of diuron under a Mediterranean climate. Agronomy for Sustainable Development, 25, 301-307. doi:10.1051/agro:2005008.

Moncada, A. (2004). Environmental fate of diuron. California Department of Pesticide Regulation Web Site. Environmental Monitoring Branch. http://www.cdpr.ca.gov/docs/empm/ pubs/fatememo/diuron.pdf Accessed 17 October 2007

Racke, K. D. (2003). What do we know about the fate of pesticides in tropical ecosystems? Environmental Fate and Effects of Pesticides ACS Symposium Series, 853, 96-123.

Reichenberger, S., Amelung, W., Laabs, V., Pinto, A., Totsche, K. U., \& Zech, W. (2002). Pesticide displacement along preferential flow pathways in a Brazilian Oxisol. Geoderma, 110, 63-86. doi:10.1016/S0016-7061(02)00182-9.

Rouchaud, J., Neus, O., Bulcke, R., Cools, K., Eelen, H., \& Dekkers, T. (2000). Soil dissipation of diuron, chlorotoluron, simazine, propyzamide, and diflufenican herbicides after repeated applications in fruit tree orchards. Archives of Environmental Contamination and Toxicology, 39, 6065. doi:10.1007/s002440010080.

Singh, N., Kloeppel, H., \& Klein, W. (2002). Movement of metolachlor and terbuthylazine in core and packed soil columns. Chemosphere, 47(4), 409-415. doi:10.1016/ S0045-6535(01)00322-8.

Southwick, L. M., Grigg, B. C., Fouss, J. L., \& Kornecki, T. S. (2003). Atrazine and metolachlor in surface runoff under typical rainfall conditions in Southern Louisiana. Journal of Agricultural and Food Chemistry, 51(18), 5355-5361. doi:10.1021/jf034049a.

Souza, M. D., Boeira, R. C., \& Gomes, M. A. F. (2000). Adsorção e dessorção de diuron em solos tropicais. Pesticidas: Revista de Ecotoxicologia e Meio Ambiente, 10, 113-124.

Syversen, N., \& Bechmann, M. (2004). Vegetative buffer zones as pesticide filters for simulated surface runoff. Ecological Engineering, 22, 175-184. doi:10.1016/j.ecoleng.2004. 05.002 .

USDA. Soil Survey Staff. (2006). Keys to soil taxonomy, 10th ed. USDA-Natural Resources Conservation Service, Washington, DC. http://soils.usda.gov/technical/classification/tax_keys/ keys.pdf.

Vianello, M., Vischetti, C., Scarponi, L., \& Zanin, G. (2005). Herbicide losses in runoff events from a field with a low slope: Role of a vegetative filter strip. Chemosphere, 61, 717-725. doi:10.1016/j.chemosphere.2005.03.043. 